\title{
The Geological History of the Pacific Ocean.*
}

By Prof. J. W. Gregory, F.R.S.

$\mathrm{T}$ HE Pacific Ocean, as the greatest geographical unit on earth, with an area greater than that of all the land, presents the difficulties as well as the attraction of its size. Its broad trigonal shape, nearly 10,000 miles wide from New Guinea to Peru, forms a striking contrast to the relatively narrow trough of the Atlantic; and the differences in size and shape render the recurrence of the same structural and biological units, which is so conspicuous with the opposite coasts of the Atlantic, less likely with the Pacific. Its 3000 islands give little evidence as to its geological history, for most of them are composed of comparatively young volcanic ejecta or coral rock.

The first striking feature of the Pacific is its apparent unity. Its surrounding lines of volcanoes, the so-called ' girdle of fire', its unstable marginal earthquake zone, the parallelism of its bordering mountain chains to its shores, the features which led Suess to describe its coasts as so different from those of the rest of the world as to constitute the Pacific Coast-type, and the association by Prior and Harker with this type of a special suite of rocks, have all supported the conclusion that the Pacific Ocean has a geographic and geological unity which indicates its permanence throughout geological time. This view, urged by Dana in 1846, has been adopted by many geologists, such as Russell Wallace, and palæontologists such as W. D. Matthew, and is supported by the recent verdict (1929) by Professor Schmidt of the Zoological Museum, Leningrad, that "The Pacific was formed in very ancient times and has undergone no important changes".

This belief in the permanence of the Pacific has been rejected by many authorities. The existence of a Pacific continent was advocated in his presidential address to the Geological Society sixty years ago, by Huxley. That the Pacific is the oldest ocean is accepted by some authorities, as von Huene, who reject its permanence. In 1899, however, I argued against the Pacific Ocean having been permanent, and expressed the view that " the Pacific Ocean may have undergone great changes later than the other oceans". To that opinion I still adhere.

Faith in the unity of the Pacific was strengthened by widely accepted theories of its origin. The view that the Pacific Basin is the hollow left when the moon was torn away from the earth is untenable, as the moon is 37 times too big and 20 per cent too heavy. The standard geological theory of the origin of the Pacific is that of Suess, who inferred from the parallelism of the surrounding mountains its unity of origin and from the marine Triassic rocks on the coasts its Triassic age.

That the margins of the Pacific have been greatly altered is certain. All authorities on the geology of the East Indies agree that they are fragments

${ }^{*}$ Presidential address to the Geological Society of London on Eeb. 21 .

No. 3159 , VoL. 125] of a continuous land, which lasted throughout the Palæozoic and extended far into the Pacific. This ancient Malaysia was continued northward as the Cathaysia of Grabau by which China extended eastward into the Ocean. Australia, it is generally accepted, was once continued eastward to Fiji and New Zealand, while Asia extended, south of Japan, to the line of the Liu Kiu and Ladrone Islands.

On the American side the former occupation of the eastern Pacific by land-the Schuchertland and Burckhardtland of von Ihering-is necessary to explain the stratigraphy of western America, the coarse conglomerates in Chile, and the sudden truncation of the structural grain of South America in Peru and in Ecuador near Paita.

On the northern side the Pacific was once occupied by the land-bridge from Mongolia to the United States, south of the Bering Sea, which was used in four different epochs by large quadrupeds. To the south the replacement of sea by land is affirmed by all those who believe in the connexion of Australia and New Zealand to South America either directly or by Antarctica.

A marginal reduction of the Pacific is, however, not enough, for many botanists, zoologists, and palæontologists, from very different lines of evidence, insist that the range of plants and animals, living and extinct, requires the existence of extensive lands in the Central Pacific, and probably of land lines nearly or wholly Trans-Pacific, such as the Archigalenis of von Ihering.

Such striking coincidences in structure as occur on the opposite sides of the Atlantic are not to be expected with the Pacific; and it may be impossible to disprove that the community of organisms in America and Asia is not due to passage across the Bering Sea: but in many cases that route is improbable, as it was not in existence at the time required, or was too far north to be in a suitable zone of latitude. Many zoologists claim that the chief Pacific islands have been peopled either by inhabitants who developed in the Central Pacific or reached the islands there by migration across a land connecting them with the continent to the south-west that occupied Polynesia.

The geological evidence is fully consistent with this conclusion. It indicates not a persistent Pacific Ocean, but the occupation of its site by a succession of narrow seas separated by land and with a predominant trend west and east. Thus in the Lower Cambrian the Olenellus Sea to the north was separated from the Redlichia Sea to the south-west; in the Middle Cambrian one sea spread from the Himalaya to the Rocky Mountains, and an arm of it, in the Upper Cambrian, overspread eastern Australia. The whole of the southern Pacific from New Zealand to South America may have been land, for the only Cambrian in South America was an arm of the Atlantic.

The Ordovician in Pupiao in southern China 
has "scarcely any trace of an American element"; the fauna there is European. China and western America had no direct marine connexion.

In the Devonian the East Indies and the China Sea were occupied by a land that extended into the western Pacific and bounded the sea by which the European fauna reached south-eastern China and Tongking. In the Middle Devonian the sea with the Flabellites fauna lay along western South America and in the valleys of the Amazon and Mississippi ; but it did not reach Australia, where, in the Upper Devonian, the Chemung fauna of New York invaded New South Wales: the absence of this fauna from Asia and California shows the separation of the north-western and south-eastern Pacific seas.

The Carboniferous had the same separation of the Asiatic and West American marine faunas; and evidence of land is given by Gigantopteris, a member of the Gondwana flora, which is found in southern and eastern China and in Texas, and doubtless entered both from a Pacific land.

The Trias has a wide range around parts of the Pacific, but was deposited in separated seas-an Arctic Ocean with a gulf to British Columbia: the western end of a southern European sea which reached Venezuela and South California; the eastern end of the same sea extended past the Himalaya to New Zealand. It is represented in New Zealand by a distinct province which was in a gulf and was not the opening to a Pacific Ocean. Evidence of trans-Pacific lands in the Trias is given, according to von Huene, by the affinities of the Triassic reptiles of South America to those of India.

The Jurassic was the time of the main development of the Pacific continent of Haug. The Liassic sea of the North Pacific was separated from the contemporary seas in Central and South America. The Malm fauna of Chile ranged westward to the Himalaya, but was different from that of the North Pacific and the European fauna in the Antillean region. The Pacific region in the Upper Jurassic according to Uhlig was occupied by faunas of four geographical provinces.

In the Cretaceous shallow water connected California and India; while later a land separated the Senonian faunas of California and Japan from that of Chile and New Zealand. The North Pacific was crossed by the giant Sauropods in their range between Mongolia and Montana, and a land route in a suitable latitude was used twice later by large quadrupeds. The South Pacific was crossed in the Cretaceous by reptiles, that migrated between South America and Asia, as the route via North and Central America was not then available. Lands west of America allowed the diffusion of the Dakota flora (Turonian) southward to the Argentine.

In the Kainozoic Era the trans-Pacific lands seem to have lasted until the Oligocene or early Miocene, since the alligator, various reptiles, amphibia, insects, crayfish, land mollusca, primitive mammals, etc., indicate migration routes across the tropical and warm temperate zones. Land plants do the same, for Asa Gray showed that the floras of China and the southern humid areas of the United States have much in common. Gordonia, one of the plants found in both areas, helps to fix the date of the migration, as it has been recently discovered by Berry in the Miocene of the Rocky Mountains.

The occurrence of similar animals and plants on opposite sides of the southern oceans has been explained by their origin in a northern land or their independent evolution. The northern monopoly of evolution is opposed by the theory of Ernst Schwarz of the southern origin of the mammals, and the evidence of the development of various animals, including some freshwater fish (vide Regan) and many plants in the southern land. The evidence of parasitology renders the alternatives to the spread of some animals across the southern Pacific, according to Launcelot Harrison, "merely grotesque".

The life of the Pacific islands, according to many authorities, can only be explained by the existence of extensive Pacific lands on which developed a Eu-Pacific fauna and flora. These lands must have been connected with Polynesia and Australasia; and were probably united to the former extension of the Andes to the north-west of Peru; according to Steinmann his Chimu-andes extended to Hawaii and Polynesia, and were cut off from South America at the end of the Eocene.

Lands survived across the Central Pacific apparently until the Lower Kainozoic ; but as the higher mammals and birds characteristic of the Upper Kainozoic are distinct on opposite sides of the Pacific, the land-bridges were destroyed before these animals could use them.

Darwin's theory of coral islands-now established by the boring at Funafuti, gravity observations on Jaluit, the widespread presence of midKainozoic foraminiferal limestones, the drowned nature of the coasts of many of the islands, and the botanical evidence from the Marquesas of their subsidence for thousands of feet-implies the sinking of a belt across the Southern Pacific during the Upper Kainozoic.

The evidence of the sedimentary rocks that the crust subsides to amounts up to 50,000 feet is opposed to the extreme form of isostasy, which denies the possible uplift of an ocean floor. The arguments in favour of that view, based on a suboceanic heavy stratum, as proved by the distribution of igneous rocks, gravity observations, and the speed of earthquake waves, rest on such doubtful assumptions that geologists should be guided by the direct geological evidence.

The long Altaid and Alpine mountains were doubtless continued across the Atlantic and the Pacific by at least raised belts. The ending of the Altaid line in the south-eastern part of the main island of Japan, and of the Alpine lines in southern China and the East Indies indicate their former extension into the Pacific. Its floor must have been disturbed by the forces that crumpled strips across the whole length of Eurasia into foldmountain chains, by the mutual pressure between the northern dome of the world and the protuberant tropical belt.

No. 3159 , Vor. 125] 